\title{
Utilization of waste heat from rotary kiln for burning clinker in the cement plant
}

\author{
Karol Sztekler 1 ,a, Maciej Komorowski², Milena Tarnowska ${ }^{3}$ and Łukasz Posak ${ }^{4}$ \\ 1,a AGH University, Faculty of Energy and Fuels, Mickiewicza Av. 30, 30-059 Krakow, Poland \\ ${ }^{2}$ AGH University, Faculty of Energy and Fuels, Mickiewicza Av. 30, 30-059 Krakow, Poland \\ ${ }^{3}$ AGH University, Faculty of Energy and Fuels, Mickiewicza Av. 30, 30-059 Krakow, Poland \\ ${ }^{4}$ Cemex Polska SP.zo.o, ul. Mstowska 10, $42-240$ Rudniki
}

\begin{abstract}
Cement subsector next to the glass industry is counted among one of the most energy-intensive industries, which absorbs approx. $12-15 \%$ of the total energy consumed by the industry. In the paper various methods of energy consumption reduction of in the cement industry are discussed. Cement production carries a very large emissions of greenhouse gases, where $\mathrm{CO}_{2}$ emissions on a global scale with the industry than approx. $5 \%$. Great opportunity in $\mathrm{CO}_{2}$ emissions reduction in addition to the recovery of waste heat is also alternative fuels co-firing in cement kilns [1], [2]. In the cement sector interest in fitting-usable waste energy is growing in order to achieve high rates of savings and hence the financial benefits, as well as the environment ones [3]. In the process of cement production is lost irretrievably lot of energy and reduction of these losses on a global scale gives a visible saving of consumed fuel. The aim of this study is to investigate the possibility of waste heat use in Rudniki Cement Plant near to Czestochowa. After analyzing of all waste heat sources will be analyzed the heat emitted by radiation from the surface of the rotary kiln at the relevant facility. On the basis of thermal-flow calculations the most favorable radiative heat exchanger will be designed. The calculations based on available measurements provided by the cement plant, a thermal power of the heat exchanger, the heat exchange surface, the geometry of the heat exchanger, and other important parameters will be established. In addition the preliminary calculations of hydraulic losses and set directions for further work will be carried out. Direct benefits observed with the introduction of the broader heat recovery technology, is a significant increase in energy efficiency of the industrial process, which is reflected in the reduction of energy consumption and costs. Indirectly it leads to a reduction of pollution and energy consumption.
\end{abstract}

\section{Introduction}

For several years there has been a trend towards the energy efficiency increase of processes and $\mathrm{CO}_{2}$ emission reduction in accordance with the European Energy and Climate Package $3 \times 20$. By reusing the recovered heat is observed: reduction of operating costs of devices (up to approx. $30 \%$ ), their energy efficiency increase, primary energy savings (fossil fuels), as well as reduction of the pollutants emission (mainly Greenhouse gases). In Poland, the level of utilization of the waste heat potential is very low, mainly due to economic issues (long payback period). Therefore, it should seek to study the subject and take the heat recovery in various industries. Cement subsector next to the glass industry is counted among one of the most energy-intensive industries, which absorbs approx. $12-15 \%$ of the total energy consumed by the industry. The cement industry carries a very large greenhouse gases emissions, where $\mathrm{CO}_{2}$ emissions on a global scale from this industry extend approx. 5\%. About half of the emissions from the calcination process occurring in rotary kilns and a half from combustion processes. In the cement sector is growing interest in fitting-usable waste energy in order to achieve high rates of savings and hence the financial benefits, as well as environmental. In the process of cement production is lost irretrievably a lot of energy and reduction of these losses on a global scale, although a fraction of a percent give a visible savings of burned fuel. In this work will be sought the best deal modernization related to the recovery of waste heat that can be made in the Cement Plant Rudniki near Czestochowa.

Waste heat recovery depends largely on the temperature and the rate of heat transfer, the availability of the day and the year. Potential and the most commonly used sources of heat recovery in cement plants are flue gases, radiation from the outer surface of the rotary kiln, the heat carried by the hot clinker leaving the furnace and cooling air for fired material. Direct benefits observed with the introduction of the broader heat recovery technology is a significant increase in energy efficiency of the industrial process, which is reflected in the reduction of energy consumption and costs. Indirectly leads to a reduction of pollution or to the consumption reduction of auxiliary energy [4].

\footnotetext{
a corresponding author: sztekler@agh.edu.pl
} 


\section{Methods for waste heat utilization in cement industry}

There are several main heat losses generated by the cement kiln installations, which can be efficiently used. These include, in particular: the flue gases from the furnace; hot air from the clinker coolers; radiation from the surface of the rotary kiln. Figure 1 illustrates the heat loss carried by the cement kiln working in the dry method. The greatest loss is the flue gas enthalpy equals of approx. $20 \%$ excess air enthalpy derived from the clinker coolers exceeding $12 \%$, and heat loss from the surface of approx. $10 \%$.

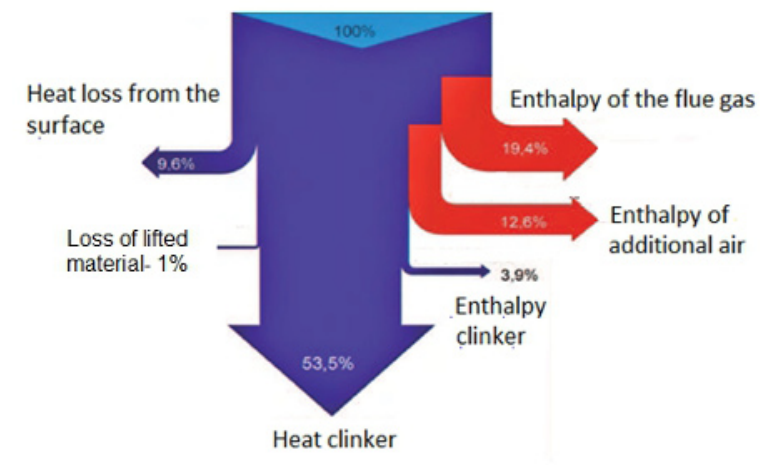

Figure 1. Heat balance of cement kiln [4]

The critical factors that affect the heat loses amount of the rotary kiln are the temperature distribution along the furnace length, thermal stability, thermal conductivity of the refractory within the furnace, environmental conditions, the thermal properties of the outer insulating layer, the rotational speed of the furnace etc. The recovered energy can be used mainly for the electricity generation or hot water preparation [5]. The total yield of the furnace depends on the mechanical efficiency, by appropriately made refrectory within the furnace and the patency of the pipe [6]. The use of waste heat is associated with a visible improvement in thermal efficiency, which translates into reduced fuel consumption, or lower operating costs.

\subsection{The use of hot air from the clinker coolers}

Rotary kilns are equipped with coolers into which the heated clinker falls out of the furnace to cooling to a temperature of approx. $100{ }^{\circ} \mathrm{C}$. Clinker cooling air heats up and is most often used as primary and secondary air for the combustion of pulverized coal in kiln burner. Furthermore, it can be a factor in drying coal and mills feedstocks. The use of hot air from the clinker cooler as primary air in the combustion of pulverized coal can save a certain amount of heat to warm the air and makes the process faster and there is a higher temperature of fuel combustion [7].

\subsection{The heat recovery from the rotary kiln}

Hot surface of the kiln, which can reach temperatures of over $400{ }^{\circ} \mathrm{C}$ is another significant source of heat loss. Convection losses and radiation may constitute approx. $8-15 \%$ of the energy input. Area of the furnace requires frequent observation by the operator to observe the local combustion of the surface, to avoid significant loss of refractory material inside the furnace. The secondary layer may be made of stainless steel, because it has a relatively low emissivity [5].

However, a more interesting use of the external heat exchanger, which are arranged around the furnace and also fulfill the task of the secondary coating but can recover greater amounts of heat.

\subsection{The use of heat of flue gases and clinker cooling air}

The most profitable in cement plant is the use of waste heat from the excess air from the clinker cooling and flue gas exiting the furnace (about 30\%). Effective heat recovery is possible by the use of cogeneration systems in which the same manufacturing process produces two products: electricity and clinker.

The flue gases from rotary kilns reach different temperatures depending on the number grades air heater. Four-stage heater supplies gas temperatures of 300-380 $\mathrm{C}$ and $5 \div 6$-stage $200-300^{\circ} \mathrm{C}$. The hot air discharged from the clinker coolers can reach $360^{\circ} \mathrm{C}$ [8]. Both streams of air and flue gases can be directed through the WHRSG steam generator (Waste Heat Recovery Steam Generator, Fig. 2). Waste energy in the cycle causes the generation of vapor, which is then used to drive a steam turbine and electricity production. The generated electricity compensates the part of the purchased energy from the power system [5]. The first implementation of the steam cycle in the cement industry took place in the $70 \mathrm{~s}$ of the last century. Hot gases flow out from rotary boiler can by used to dry coal in cement plant. Currently this technics utilization heat from flue gases is implemented in many installation for instant in Rudniki Cement Plant.

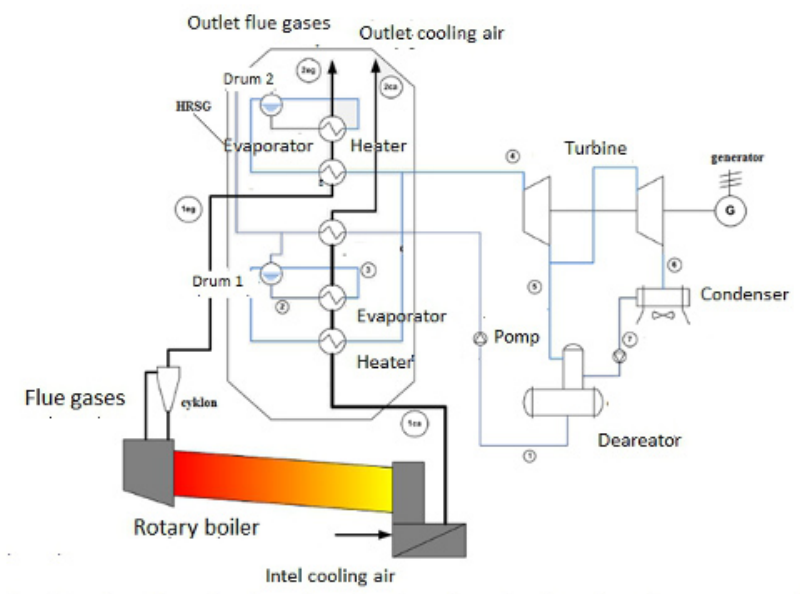

Figure 2. The waste heat recovery system with the ClausiusaRankine water - steam cycle [8]

There is also the possibility of electricity generation in a cement plant in other cogeneration cycles: an Organic Rankine cycle (ORC), Kalina cycle, or in the piston steam engine. Very preferred because of its low installation cost and increased efficiency is the use of the TFC system (Trilateral Flasch Cycle) in screw engines where there is no water evaporation, but the expansion with evaporation [11].

Organic Clausius-Rankine cycle (ORC) is often used to recover heat from the energy-intensive production 
processes in industries: cement, iron, glass industry, the oil and gas industry. ORC is the most effective technology for the recovery of heat and electricity, if it uses a heat source temperatures of 200-400 ${ }^{\circ} \mathrm{C}$. However, ORC cycle efficiency is limited, and typical examples reach up to approx. $20 \%$.

Figure 3 presents the example of ORC cycle in which there is water flow at high pressure of 30 bar. The first choice of working medium for ORC system is isopentane, because of the highest achievable efficiency of the cycle.

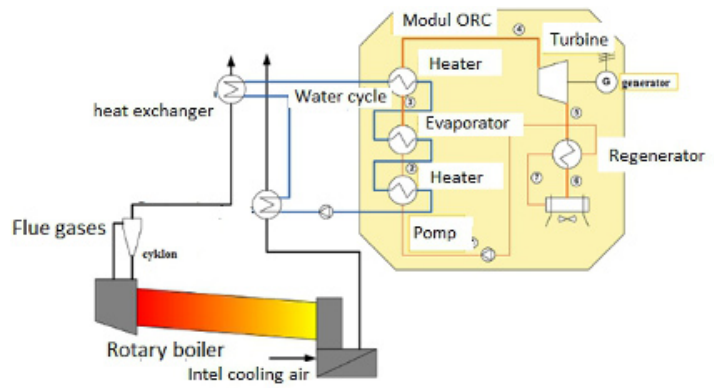

Figure 3. The heat recovery system using the ORC [8]

CR water Steam cycle is more efficient than the ORC when the flue gas temperature is greater than $310^{\circ} \mathrm{C}$. For cement plants that use old technology and flue gas temperature is high, preferred system is the use of waste heat recovery system with CR water steam cycle. But for modern cement plants with higher efficiency and lower temperatures there is advisable to use ORC system [8]. In addition, ORC cycle is more flexible and disposable, can operate at a partial load, and has a wide range of stable operation, while the water steam cycle needs a stable and more uniform operation conditions [9].

The association of rotary kiln with the electricity generation system is beneficial in terms of economic, environmental, and energy for cement plants. Cogeneration among others: facilitates uninterrupted operation of the furnace, apparently increases fuel efficiency, reduces the consumption of refractory materials and allows for higher clinker quality.

According to [9] in the EU-27, there were 259 cement plants, 389 rotary kilns with a total capacity of 247.8 Mt/year. It was estimated that 241 cement plants is possible to use ORC systems whose production potential could reach approx. $576 \mathrm{MW}$. However, this work is focused on the possibility of heat recovering from the cement shell of the rotary cement kiln which generates more than $10 \%$ of the heat losses.

\section{Disposal of waste heat in the Rudniki Cement Plant}

The possibilities of waste heat use from the cement industry are very large and provide a significant economic and environmental savings, associated with emissions reduction. In this paper, an analysis of the use of waste heat emitted by the radiation cement kiln in the Rudniki Cement Plant near to Czestochowa is presented. Calculations of two variants of the heat exchangers characterized by different dimensions, power and the degree of coverage of the heating needs of the plant were performed.
Then construction solution of the radiation heat exchanger is designed and directions for further work was suggested. Currently in the cement plant are 2 utilization ways of waste heat emitted by the installation of the rotary kiln. Produced clinker is cooled in a grate cooler and for cooling process is use cold air. The heated air by the hot clinker is used as secondary air into the furnace, the heat losses are smaller and the heating process of the supplied material is faster. In 2003 the hot gases pipeline received from the furnace which are used for drying of the raw material fed for the raw meal preparation in two ball mills with capacities of $115 \mathrm{t} / \mathrm{h}$ and $40 \mathrm{t} / \mathrm{h}$. In $2014 \mathrm{t}$ another second pipeline of flue gases supplied to the coal department was built, where they are used for coal drying in a ball mill. The process is very safe, due to the reduced content of $\mathrm{O}_{2}$ in the gases $(4-8 \%)$. Both formed pipes are derived from the dusts chamber. There is no heat recovery from the rotary kilns.

\subsection{The concept of heat recovery from the rotary kiln}

Rotary kilns by radiation, emit substantial amounts of heat which can be usefully used, eg. for domestic hot water heating used to meet the needs of the plant. The heat to the ambient air through the rotary kiln takes place by radiation and convection. However, in the zone of highest temperature is dominated by heat transfer through radiation (approx. 4 times higher heat transfer coefficient by radiation than convective one) [10].

The heat exchanger must be placed in the zone of the furnace, where the highest temperature, at an appropriate distance from the kiln shell. Taking into account the operational and technological considerations, heat exchanger must not obstruct the operation, repair work or maintenance, so it is expected to placement in suitable distance from the kiln.

Heat exchanger distance from the furnace should be as small as possible, but the above reasons, considering the application of the mechanism governing this distance. Most preferred would be to place the heat exchanger above the kiln, but for the implementing reasons heat exchanger will be located under the furnace equipped with a frame on wheels that can be easily moved. In addition, it can't be in the area of the furnace throat, wherein the diameter changes from $3.45 \mathrm{~m}$ to $3,75 \mathrm{~m}$, in areas where supports are provided, and where run frequently used road transport. Figure 4 shows the selected location of the radiation heat exchanger placement at a rotary kiln no. 4 .

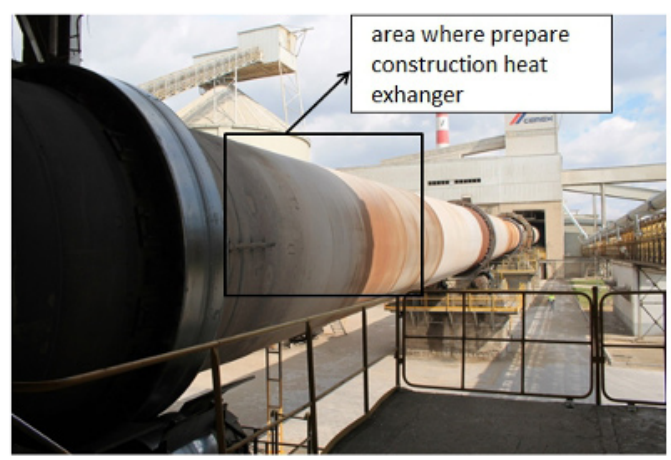

Figure 4. Rotary boiler number 4 


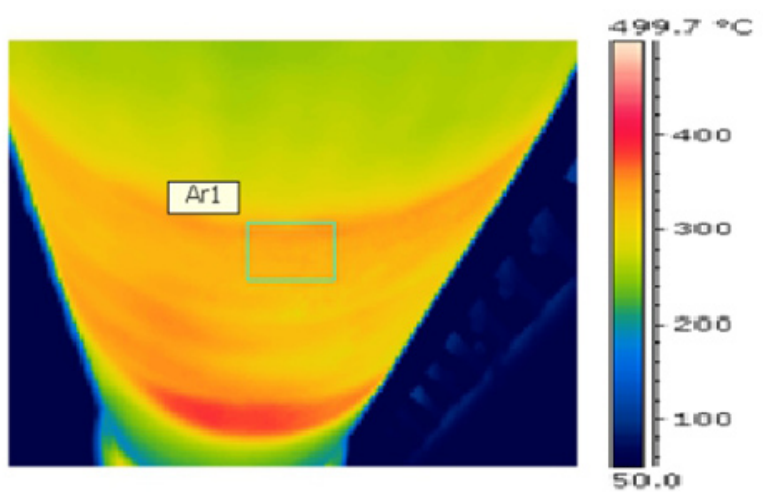

Figure 5. Distribution of kiln shell temperature in section of 16$28 \mathrm{~m}$

Thermal imaging was used for calculations to measure the temperature distribution on the mantle of the furnace (Fig. 5) in a section of 16-28 minitial length of the furnace, where there was on a selected range of Ar1 a time maximum temperature of $348.7^{\circ} \mathrm{C}$.

Two variants of heat exchangers with different lengths will be taken into consideration. For comparison

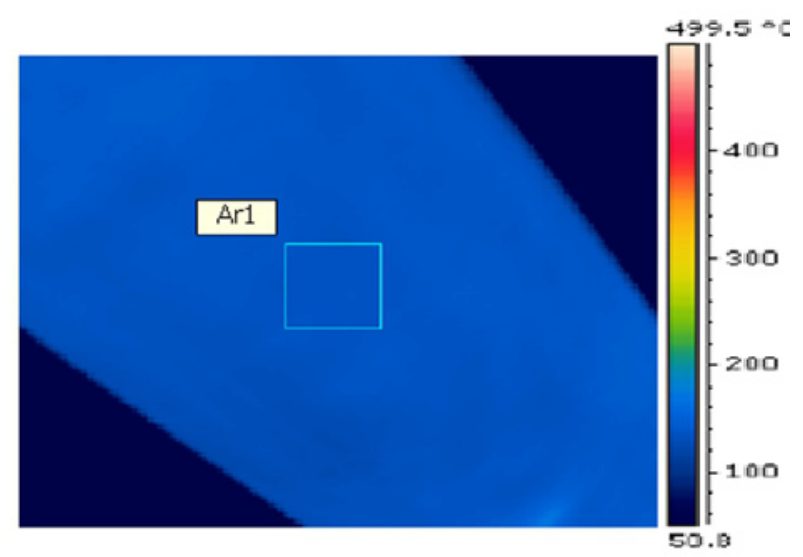

Figure 6. Temperature distribution of kiln shell in section of 100$110 \mathrm{~m}$

Figure no. 6 shows the temperature distribution along the length of $100-110 \mathrm{~m}$, where is a maximum temperature of $136.1^{\circ} \mathrm{C}$ in Area Ar 1 . The temperature at this length has a more uniform distribution, but it is not energy profitable to use.

\subsection{Design assumptions}

It was assumed that the heat exchanger will be made in the form of single-screen seamless steel pipes. The screen will be made in the form of cylinder surface covering $1 / 6$ of the circumference of the rotary kiln, which is the solid angle of $60^{\circ}$ at a minimum distance of $1 \mathrm{~m}$ from the kiln.

The calculation of the configuration factor and heat flux absorbed by the wall of the heat exchanger of the rotary kiln, the thermal power consumed by the heat exchanger, water velocity in the exchanger tubes, hydraulic losses, heat flux acquired by the exchanger tubes of the rotarykiln were made on the basis of literature references $[12,13,14]$. Heat exchanger will be equipped with a mechanism for increasing its distance from the kiln shell.

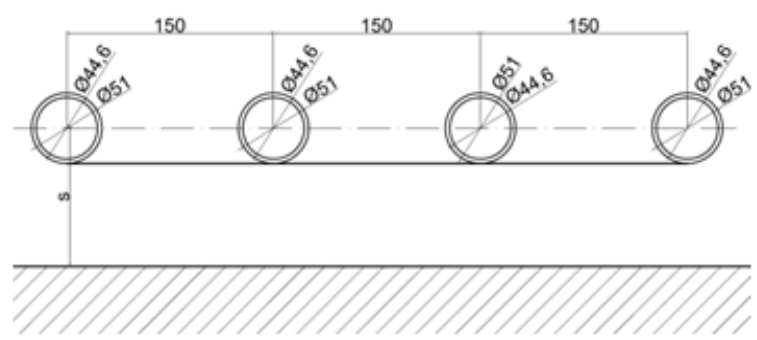

Figure 7. Founded screen size with irradiated pipes: s- exchanger distance from the rotary kiln

Seamless steel boiler pipes were adopted with dimensions:

$\frac{d_{z}}{d_{w}}=\frac{51 \mathrm{~mm}}{44,6 \mathrm{~mm}}$, which will be connected by elbows and welded to the screen made of steel. The distance between the pipes was assumed at $0.15 \mathrm{~m}$ (Fig.6). The water will flow through the tubes receiving the heat from radiation, the outlet temperature will equal of $65^{\circ} \mathrm{C}$ and will be used to satisfy the own needs of cement plant.

Other assumptions for the calculations:

- averaged temperature of kiln shell in section 16-28m;

- averaged temperature of kiln shell in section 16-24m,

- exchanger body length $l_{1}=12 \mathrm{~m}, l_{2}=8 \mathrm{~m}$,

- the maximum daily consumption of hot water in the cement plant in 2014 increased by approx. $30 \%-10 \mathrm{~m}^{3}$, which is the average volume flow of $0.12 \mathrm{l} / \mathrm{s}$.

The calculations were performed for the temperature of the heat exchanger wall pipe $t_{2}$ from 37.6 at $0.1{ }^{\circ} \mathrm{C}$ (values exceeding the value of the reference temperature $t_{f m}$ ) for comparing the obtained values of the intensity of the heat flux emitted by radiation through the rotary kiln and absorbed (acquired) through the heat exchanger to choose the right temperature.

Designed heat exchanger coil is recuperator, or apparatus in which two factors: air and water are separated from each other by the pipe wall through which the heat transfer. It is a device in which the temperature field is established and the heat exchange process is continuous.

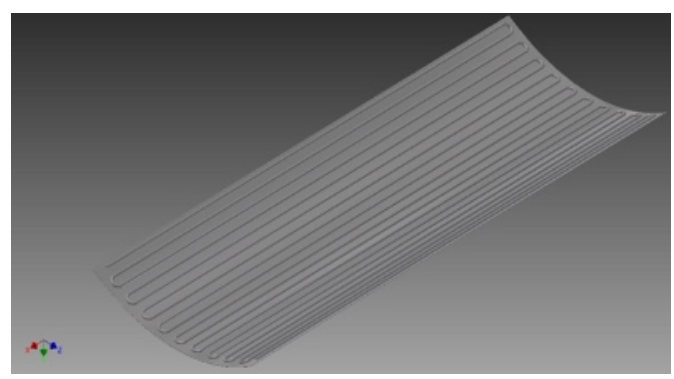

Figure 8. Designed radiation heat exchanger

For the calculations carried out for a heat exchanger minimum distance from the heat exchanger furnace $\mathrm{s}=1$ $\mathrm{m}$ is designed (Fig. 7,8) wherein: the length of the heat exchanger $l \approx 8 \mathrm{~m}$, the maximum thermal power $\dot{Q} \approx 65 \mathrm{~kW}$; the speed of flowing water $v=0.182 \div 0.023$ $\mathrm{m} / \mathrm{s}$; the water exit temperature from the heat exchanger $t_{w y}=65^{\circ} \mathrm{C}$; volume flow $\dot{V}=0,285 \div 0,036 \mathrm{dm}^{3} / \mathrm{s}$; size of hydraulic losses $\Delta h_{c}=0,204 \div 0,006 \mathrm{~m}$; heat exchanger pipe diameters: $d_{z}=51 \mathrm{~mm}, d_{w}=44,6 \mathrm{~mm}$; the length 
of the coil $L \approx 161 \mathrm{~m}$; the amount of steel tubes $n=20$; the number of $90^{\circ}$ elbows $n_{k}=38$; steel screen size $8,4 \mathrm{~m} \times 3,19 \mathrm{~m}$; Screen thickness of steel plate: $\delta=6 \mathrm{~mm}$; the total weight of the heat exchanger $>1.34 \mathrm{t}$.

Figure 8 shows a heat exchanger visualization, and Fig. 9 an exemplary installation in which the heat exchanger can be operated.

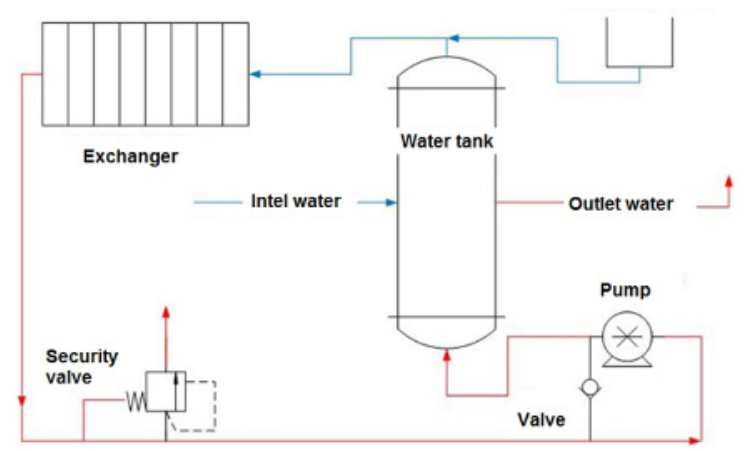

Figure 9. Domestic hot water installation diagram using the designed coil heat exchanger.

It is necessary to equipe an installation in domestic hot water tank of high-capacity, eg. $3000 \div 50001$. Additionally, a buffer tank can be used to the accumulation of excess recovered heat eg. using PCM phase change materials. It is proposed that the exchanger is mounted on the movable platform with dimensions that ensure the stability of the structure. The platform can move on 6 steel rolls, which are movable on steel rails (due to the need to move apart during the overhaul of the furnace heat exchanger, the heat exchanger and in other situations where the heat exchanger is impeded of the kiln). Implementation of the exchanger distance control to the rotary kiln, depending on the demand of domestic hot water may be carried out by a hydraulic system.

\section{Conclusions}

Thanks to designed heat exchanger with a maximum capacity of approx. $65 \mathrm{~kW}$ cement plant will reach a high efficiency of burned fuel. The plant will be able to afford to completely disable the boiler room in summer (May-September), while in winter they will be aided working exchanger. Due to the relatively low density of the heat flux emitted by the kiln shell designed heat exchanger has a fairly large dimensions.

A very important element is to provide a heat exchanger in a continuous temperature measurement of the water input and output, which will give an indication to the approximation, or the heat exchanger distance from the kiln shell depending on the current needs of the plant for the domestic hot water. It is also possible to build several heat exchangers connected together in parallel and, thus, would be a greater amount of heated water, which would be justified when provided would be the continuous reception. The heat exchangers can also be arranged on the sides and top of the rotary kiln so would also be used with a convection heat from it, but this would lead to high costs and possible difficulties during the operation of the kiln. The way to the use of excessive waste heat is possible to prepare a central domestic hot water for eg. a nearby housing estate. However, this requires significant financial investment, eg. from the local government and the residents.

In summary, designed variant of the heat exchanger is a simple and relatively inexpensive investment for easy installation in a cement plant. The rotary kiln does not require the exclusion of the time of installation. In addition, heat has no influence on the quality of the final material produced in the plant and the whole technological process.

\section{Ackowledgements}

The article was funded from government money Faculty of Energy and Fuels number 11.11.210.216

\section{References}

1. E. Mokrzycki, A. Uliasz-Bocheńczyk, Polityka Energetyczna, 9, 1 (2006)

2. N.A. Madlool, R. Saidur, M.S. Hossain, N.A. Rahim, Renew. Sust. Energ. Rev. 15, (2011)

3. A. Atmaca, R. Yumrutas, App. Therm. Eng. 66, (2014)

4. J. Duda, Dlaczego ORC jest najlepszym rozwiazaniem do wykorzystania energii odpadowej w cementowni? Prace Instytutu Ceramiki i Materiałów Budowlanych, Wydawnictwo Instytut Śląski Sp. z o.o, s.32-43 (2012)

5. T. Engin, V. Ari, Energ. Convers. Manage. 46, (2005) 6. Projekt decyzji BC-10. Zalecenia techniczne dotyczace bezpiecznego środowiskowo wspótprzetwarzania niebezpiecznych odpadów w piecach cementowych. Kartagena, Kolumbia, Konferencja Stron Konwencji Bazylejskiej (2011).

7. S. Żurakowki, S. Hojarczyk, Piece obrotoweprojektowanie i konstrukcja. Warszawa, WNT (1969).

8. S. Karellas, A. Leontaritis, G. Panousis, E. Kakaras, Energy 58, (2013)

9. F. Campana, M. Bianchi, L. Branchini, A. De Pascale, A. Peretto, M. Baresi, Energ. Convers. Manage. 76, (2013)

10. M. Poniewski,T. Orzechowski, Cz. Cesarz, R. Chajewski, K. Gołaszewski, M. Lubowicz, Utylizacja ciepła odpadowego cz. II, Zlec. nr 1839/13, Kielce, Politechnika Świętokrzyska, Samodzielny Zakład Termodynamiki i Mechaniki Płynów (1993).

11. J. Duda, Dlaczego ORC jest najlepszym rozwiazaniem do wykorzystania energii odpadowej w cementowni?. Prace Instytutu Ceramiki i Materiałów Budowlanych, Wydawnictwo Instytut Śląski Sp. z o.o., s.32-43 (2012). 12. J. P. Holman, Heat Transfer. 10th Edition, Nowy York, McGraw-Hill (2010).

13. T. Hobler, Ruch ciepła $i$ wymienniki. Warszawa, Państwowe Wydawnictwa Techniczne (1959).

14. U. Lubczyńska, Hydraulika stosowana. Kielce, Politechnika Świętokrzyska (1996). 